Supporting Information

\title{
Assembly of a ribozyme ligase from short oligomers by nonenzymatic ligation
}

Lijun Zhou, ${ }^{\dagger, \ddagger, \nabla}$ Derek K. O’Flaherty, ${ }^{\dagger, \ddagger, \perp, \nabla}$ and Jack W. Szostak ${ }^{*, \dagger, \neq, \S}$

†Howard Hughes Medical Institute, Department of Molecular Biology and Center for Computational and Integrative Biology, Massachusetts General Hospital, 185 Cambridge Street, Boston, Massachusetts 02114, USA.

Department of Genetics, Harvard Medical School, 77 Avenue Louis Pasteur, Boston, Massachusetts 02115, USA.

$\S$ Department of Chemistry and Chemical Biology, Harvard University, 12 Oxford Street, Cambridge, Massachusetts 02138, USA.

$\nabla$ These authors contributed equally to this work.

*Correspondence to: szostak@molbio.mgh.harvard.edu

${ }^{\perp}$ Present address: Alnylam Pharmaceuticals, 300 Third Street, Cambridge, Massachusetts 02142, USA. 


\section{Table of Contents}

Experimental Procedures $\quad$ S3

$\begin{array}{ll}\text { Supporting Figure S1-S5 } & \text { S5 }\end{array}$

$\begin{array}{ll}\text { Table S1-S2 } & \text { S10 }\end{array}$

$\begin{array}{ll}\text { References } & \text { S12 }\end{array}$ 


\section{Experimental Procedures}

\section{Chemical synthesis of $\mathbf{3}^{\prime}$-amino nucleotide phosphoramidites}

Protected $3^{\prime}$-amino phosphoramidites were prepared as reported ${ }^{1}$. All chemical reagents were purchased from Sigma-Aldrich unless otherwise indicated. $3^{\prime}$-Amino$2^{\prime}, 3^{\prime}$-dideoxycytidine was purchased from Carbosynth (Campton, UK). $3^{\prime}$-Amino$2^{\prime}, 3^{\prime}$-dideoxyguanosine, $3^{\prime}$-amino-2', $3^{\prime}$-dideoxyadenosine and $3^{\prime}$-amino-2', $3^{\prime}$ dideoxythymidine were purchased from Fisher/Alfa Aesar (Haverhill, MA).

\section{Solid phase synthesis of non-activated oligonucleotides}

$3^{\prime}$-Amino oligonucleotides were synthesized with reverse phosphoramidites. Other oligonucleotides were synthesized with regular phosphoramidites. CPG columns, phosphoramidites and chemical reagents for RNA synthesis were purchased from Glen Research (Sterling, VA) and Chemgenes (Wilmington, MA). DNA oligomers were ordered from IDT (Newark, NJ). Oligonucleotides were prepared by solidphase synthesis on an Expedite 8909. After synthesis, RNAs were cleaved from the column by $2 \mathrm{ml}$ AMA solution 1 : 1 mixture of $28 \% \mathrm{NH}_{4} \mathrm{OH}$ aqueous solution and $40 \%$ methylamine aqueous solution) at room temperature for 30 mins, and then deprotected at $65{ }^{\circ} \mathrm{C}$ for 20 mins. The deprotection products were dried in vacuo. The powders were resuspended in $100 \mu \mathrm{l}$ DMSO, $60 \mu \mathrm{l}$ TEA and $75 \mu \mathrm{l} \mathrm{TEA.3HF,} \mathrm{then}$ incubated at $65{ }^{\circ} \mathrm{C}$ for 2.5 hours to remove TBDMS protecting groups. Non-dyelabeled oligonucleotides were purified on GlenPak columns by the DMT-on method. Dye-labeled oligos were purified by polyacrylamide gel electrophoresis and desalted with Sep-Pak C18 cartridges from Waters (Milford, MA).

\section{Activated Oligonucleotides}

5 '-Phosphorylated RNA ligators were activated with 2-methylimidazole as previously described ${ }^{2,3}$ with minor modifications as follows. The RNA product from a $1 \mu$ mole synthesis was purified on a Glenpak column, then resuspended in $100 \mu \mathrm{l}$ of DMSO in a screw-cap $1.5 \mathrm{ml}$ tube. Then $4.2 \mu \mathrm{l}$ TEA (30 $\mu$ mole), $1.6 \mathrm{mg} 2$ methylimidazole $(20 \mu \mathrm{mole}), 5.2 \mathrm{mg}$ triphenylphosphine $(20 \mu \mathrm{mole})$ and $4.4 \mathrm{mg}$ dipyridyl-disulfide $(20 \mu$ mole $)$ were added. The reaction was incubated on a rotator for 5 hours, then precipitated in $1 \mathrm{ml}$ acetone and $100 \mu \mathrm{NaClO}_{4}$-saturated acetone. Activated ligators then were purified by HPLC on Agilent ZORBAX analytical columns (Eclipse Eclipse Plus C18, $250 \times 4.6 \mathrm{~mm}, 5 \mu \mathrm{m}$ particle size, P.N. 959990902), at a flow rate of $1 \mathrm{ml} / \mathrm{min}$, using gradient elution between (A) aqueous $20 \mathrm{mM}$ triethylammonium bicarbonate, $\mathrm{pH} 8.0$, and (B) acetonitrile, from $6 \%$ to $10 \% \mathrm{~B}$ over 17 minutes.

\section{Triphosphate Oligonucleotide preparation}

The 14-nt 5'-triphosphate substrate of the ribozyme ligase was synthesized by in vitro transcription using a HiScribe ${ }^{\mathrm{TM}} \mathrm{T} 7 \mathrm{High}$ Yield RNA Synthesis Kit (New England Biolabs, Ipswich, MA) and purified by 20\% (19:1) denaturing PAGE with 7 M urea. 


\section{High-resolution mass spectrometry}

Oligonucleotides were analyzed on an Agilent 1200 HPLC coupled to an Agilent 6230 TOF mass spectrometer. Samples were resolved by IP-RP-HPLC on a $100 \mathrm{~mm}$ $\times 1 \mathrm{~mm}$ Xbridge C18 column with $3.5 \mu \mathrm{m}$ particle size (Waters, Milford, MA) using gradient elution between (A) aqueous $200 \mathrm{mM}$ 1,1,1,3,3,3-hexafluoro-2-propanol with $1.25 \mathrm{mM}$ triethylamine, $\mathrm{pH} 7.0$, and (B) methanol. Samples were analyzed in negative mode from $239 \mathrm{~m} / \mathrm{z}$ to $3200 \mathrm{~m} / \mathrm{z}$ with a scan rate of 1 spectrum/s.

\section{Nonenzymatic Ligation Reactions}

Reactions were set up as described in the manuscript. All components were mixed together on ice. At each time point, an $0.25 \mu \mathrm{l}$ aliquot of the reaction mixture was added to $40 \mu \mathrm{l}$ of quenching buffer, containing $50 \mathrm{mM}$ EDTA, 1 x TBE buffer and $8 \mathrm{M}$ urea. Quenched samples were heated to $95^{\circ} \mathrm{C}$ for $1 \mathrm{~min}$ and cooled quickly to room temperature $\left(\sim 25^{\circ} \mathrm{C}\right)$. Primer extension products were resolved by $12 \%$ (19:1) denaturing PAGE with $7 \mathrm{M}$ urea. T the Cy3 labeled primer and ligated products were detected and imaged with an Amersham RGB Biomolecular Imager (GE Healthcare Life Science, Marlborough, MA) and quantified with the ImageQuant ${ }^{\mathrm{TM}}$ software package (GE Healthcare Life Science, Marlborough, MA). The nonenzymatic ligation products were stored at $-80^{\circ} \mathrm{C}$ for subsequent ribozyme ligase activity tests.

\section{Ribozyme Ligase Activity Tests}

Nonenzymatic ligation samples were thawed, diluted 10 -fold in a reaction buffer containing $50 \mathrm{mM}$ bis-tris propane, $\mathrm{pH} 8.5,3 \mu \mathrm{M} 5^{\prime}$-triphosphate RNA substrate, 25 $\mathrm{mM} \mathrm{MgCl} 2$ and incubated at $48^{\circ} \mathrm{C}$. At each time point, a $1 \mu \mathrm{l}$ aliquot of the reaction mix was added to $15 \mu \mathrm{l}$ of quenching buffer containing $50 \mathrm{mM}$ EDTA, 1 x TBE buffer and $8 \mathrm{M}$ urea. The enzymatic ligation products were resolved by 12\% (19:1) denaturing PAGE with $7 \mathrm{M}$ urea and imaged with an Amersham RGB Biomolecular Imager. 


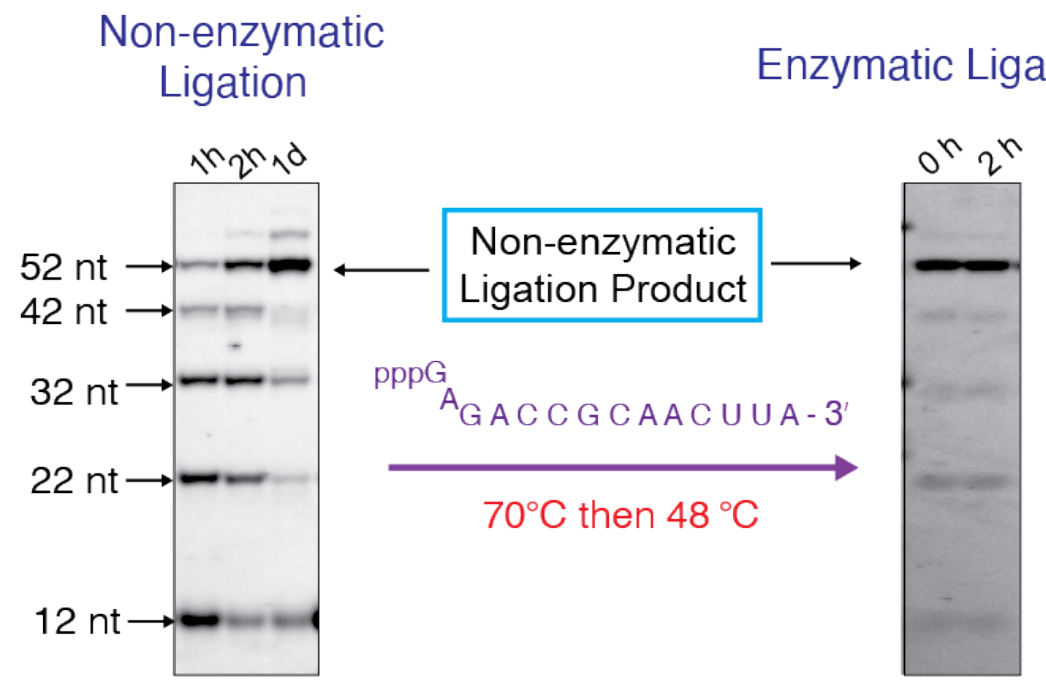

\section{Figure S1:}

Strong ligase inhibition by 10 -nt RNA splints, despite a 50 -fold dilution and a $70^{\circ} \mathrm{C}$ heat denaturing step. Left, assembly of the 52-nt ribozyme ligase by nonenzymatic ligation (same gel as Figure 2b left). Right, PAGE analysis showing the lack of activity of the product ligase. The nonenzymatic ligation product was diluted 50 -fold into the ribozyme reaction buffer: $50 \mathrm{mM}$ bis-tris propane, $\mathrm{pH} 8.5,25 \mathrm{mM} \mathrm{MgCl}_{2}$ and 5 $\mu \mathrm{M}$ triphosphate substrate. The ligase reaction was heated to $70^{\circ} \mathrm{C}$ for 1 minute then cooled to $48^{\circ} \mathrm{C}$. No ligase activity was detected. 


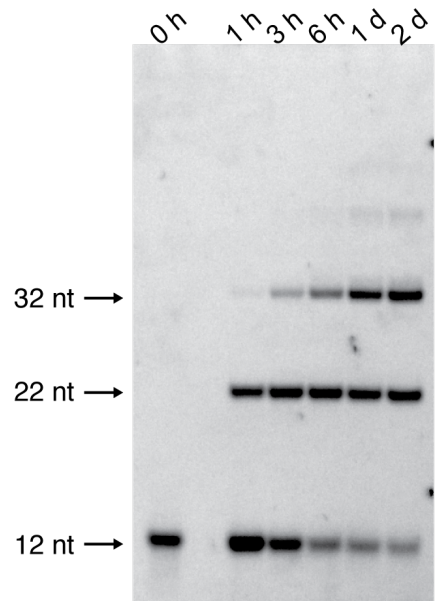

Figure S2:

Poor efficiency of ribozyme assembly with 8-nt RNA splints. The ribozyme assembly reaction was carried out on ice with $90 \mu \mathrm{M}$ of ligator $1,100 \mu \mathrm{M}$ of ligators 2 to $\mathbf{5}$, $100 \mu \mathrm{M}$ of 4 different 8-nt RNA splints (5'-AGUGAUAA-3', 5'-UUACGUAA-3', 5' AAAGUGUU-3', 5'-CAACCCAU-3'), $200 \mathrm{mM}$ HEPES, pH 8.0, $100 \mathrm{mM} \mathrm{NaCl}, 1 \mathrm{mM}$ EDTA, $50 \mathrm{mM} \mathrm{MgCl} 2$ and $100 \mathrm{mM}$ HEI. 


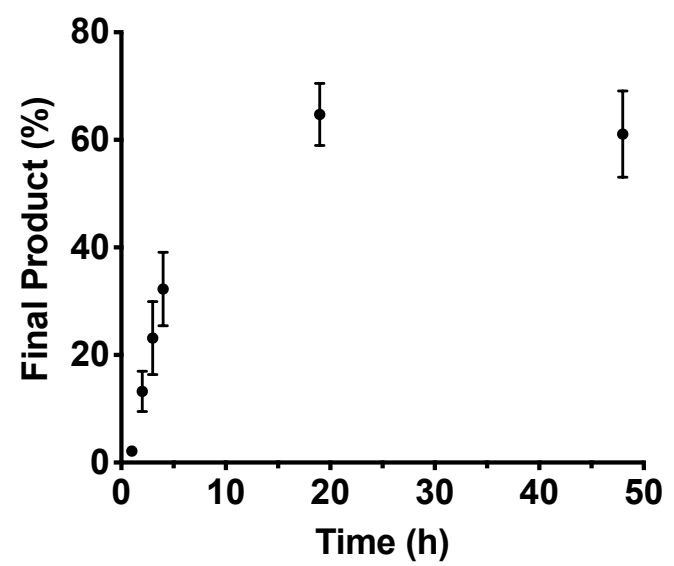

\section{Figure S3:}

Yield of full-length RNA ligase assembly by nonenzymatic ligation using DNA splints, as shown in Figure 3. The error bars show S.D. from triplicate experiments. 


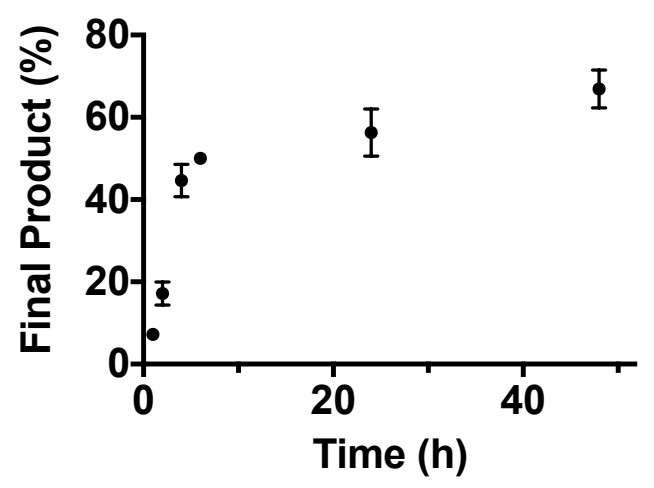

\section{Figure S4:}

Yield of full-length RNA ligase assembly by nonenzymatic ligation using G:U wobble pairing RNA splints, as shown in Figure 4. The error bars show S.D. from triplicate experiments. 


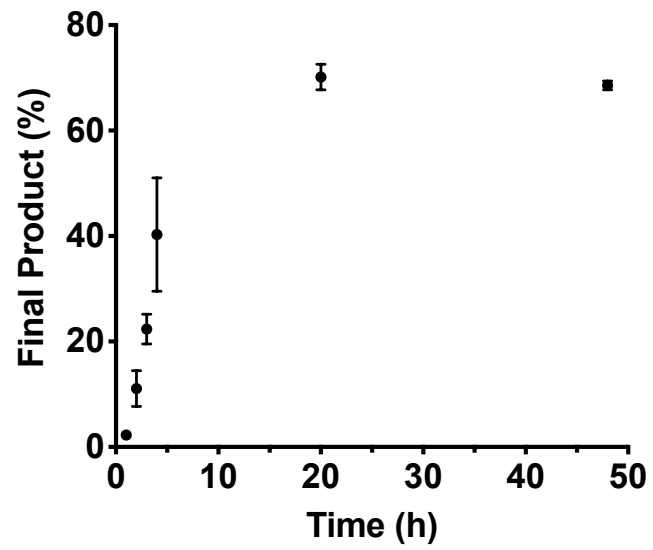

Figure S5:

Yield of full-length RNA ligase assembly by nonenzymatic ligation using I:C wobble pairing RNA splints, as shown in Figure 5. The error bars show S.D. from triplicate experiments.

Sq 
Table S1: Summary of oligonucleotides sequences used in this study*

\begin{tabular}{|c|c|}
\hline Name & Sequence $\left(5^{\prime} \rightarrow 3^{\prime}\right)$ \\
\hline Ligator 1 & Сy3-GG AAGUU GUUAT ${ }_{\mathrm{NH} 2}$ \\
\hline Ligator 2 & /2-MeImp/ CACUU GUUAC ${ }_{\mathrm{NH} 2}$ \\
\hline Ligator 3 & /2-MeImp/ GUAAG UAACA ${ }_{\mathrm{NH} 2}$ \\
\hline Ligator 4 & /2-MeImp/ CUUUG GAUGG ${ }_{\mathrm{NH} 2}$ \\
\hline Ligator 5 & /2-MeImp/GUUGA AGUAU \\
\hline Splint 1 & AAGUG AUAAC \\
\hline Splint 2 & CUUAC GUAAC \\
\hline Splint 3 & CAAAG UGUUA \\
\hline Splint 4 & UCAAC CCAUC \\
\hline Splint 5 & d(AAGTG ATAAC) \\
\hline Splint 6 & d(CTTAC GTAAC) \\
\hline Splint 7 & d(CAAAG TGTTA) \\
\hline Splint 8 & d(TCAAC CCATC) \\
\hline Splint 9 & AAGUG AUAAU \\
\hline Splint 10 & CUUAU GUAAU \\
\hline Splint 11 & UAAAG UGUUA \\
\hline Splint 12 & CAAC CUAUU \\
\hline Splint 13 & AAIUI AUAAC \\
\hline Splint 14 & CUUAC IUAAC \\
\hline Splint 15 & CAAAI UIUUA \\
\hline Splint 16 & CAAC CCAU \\
\hline Ligase Substrate & pppGAGA CCGCA ACUUA \\
\hline
\end{tabular}

*All sequences are RNA unless otherwise specified. DNA is labeled with ' $d$ '. 3'amino-2',3'-dideoxy-ribonucleotides are labeled in red. "ppp" stands for triphosphate, "I" stands for inosine. 
Table S2: Estimated melting temperatures of the splints and the nonenzymatic ligation product

\begin{tabular}{|c|c|c|c|c|}
\hline Name & Sequence $\left(5^{\prime} \rightarrow 3^{\prime}\right)$ & $\begin{array}{l}\text { Calculated } \mathrm{T}_{\mathrm{m}} \\
\text { (1M NaCl) }\end{array}$ & $\begin{array}{c}\Delta \mathrm{T}_{\mathrm{m}} \\
\text { (compared to } \\
\text { respective } \\
\text { splints } 1-4 \text { ) }\end{array}$ & $\begin{array}{c}\text { Calculated } \mathrm{T}_{\mathrm{m}} \\
(25 \mathrm{mM} \mathrm{MgCl} \text {, } \\
10 \mathrm{mM} \mathrm{NaCl})\end{array}$ \\
\hline Splint 1 & AAGUG AUAAC & 47.7 & & 47.9 \\
\hline Splint 2 & CUUAC GUAAC & 48.3 & & 48.5 \\
\hline Splint 3 & CAAAG UGUUA & 46.1 & & 46.2 \\
\hline Splint 4 & UCAAC CCAUC & 62.3 & & 62.6 \\
\hline Splint 5 & d(AAGTG ATAAC) & 27.5 & -20.2 & \\
\hline Splint 6 & d(CTTAC GTAAC) & 34.8 & -13.5 & \\
\hline Splint 7 & d(CAAAG TGTTA) & 32.0 & -14.1 & \\
\hline Splint 8 & d(TCAAC CCATC) & 48.6 & -13.7 & \\
\hline Splint 9 & AAGUG AUAAU & 42.9 & -4.8 & \\
\hline Splint 10 & CUUAU GUAAU & 34.8 & -13.5 & \\
\hline Splint 11 & UAAAG UGUUA & 40.0 & -6.1 & \\
\hline Splint 12 & CAAC CUAUU & 38.1 & -24.2 & \\
\hline Splint 13 & AAIUI AUAAC & 35.2 & -12.5 & \\
\hline Splint 14 & CUUAC IUAAC & 43.3 & -5 & \\
\hline Splint 15 & CAAAI UIUUA & 33.9 & -12.2 & \\
\hline Splint 16 & CAAC CCAU & 48.2 & -14.1 & \\
\hline
\end{tabular}

The calculation is based on the reported thermodynamic parameters ${ }^{4-7}$, with the equation:

$$
T_{m}=\frac{\sum \Delta H}{\sum \Delta S+R \ln \left(\frac{C}{4}\right)}-273.15
$$

Here, $\mathrm{R}$ is $1.987 \mathrm{cal} \bullet \mathrm{K}^{-1} \bullet \mathrm{mol}^{-1}$, and $\mathrm{C}$ is the total strand concentration. An estimated increase of $\mathrm{T}_{\mathrm{m}}$ affected by one phosphoramidate backbone modification is included ${ }^{8}$. All reported $\Delta H$ and $\Delta S$ values are from experiments in $1 \mathrm{M} \mathrm{NaCl}$. The correction of $\mathrm{T}_{\mathrm{m}}$ for different concentrations of $\mathrm{Na}^{+}$and $\mathrm{Mg}^{2+}$ has only been reported for DNA duplexes ${ }^{9}$.

When $\left[\mathrm{Na}^{+}\right]=10 \mathrm{mM},\left[\mathrm{Mg}^{2+}\right]=25 \mathrm{mM}$ :

$$
\begin{aligned}
\frac{1}{T_{m}(\operatorname{Corr})}= & \frac{1}{T_{m}(1 M N a)}+[[3.92-0.911 \ln [M g]+f \times(6.26+1.42 \ln [M g]) \\
& +\frac{1}{2(N-1)} \times\left(-48.2+52.5 \ln [M g]+8.31 \ln ^{2}[M g]\right] \times 10^{-5}
\end{aligned}
$$

Here, $\mathrm{f}$ is the fraction of GC base pairs and $\mathrm{N}$ is the number of base pairs.

We calculated the $T_{m}$ of the RNA duplexes in our experimental conditions $(10 \mathrm{mM}$ $\mathrm{NaCl}, 25 \mathrm{mM} \mathrm{MgCl}_{2}$ ) with the same equation as used for DNA duplexes and found 
that the change of $T_{m}$ is not significant. The calculations presented above for DNA, wobble pairing and inosine containing splints are not adjusted for the changed salt and $\mathrm{Mg}^{2+}$ concentrations and are therefore only approximate.

\section{References}

(1) Lelyveld, V. S.; O’Flaherty, D. K.; Zhou, L.; Izgu, E. C.; Szostak, J. W. DNA Polymerase Activity on Synthetic N3' $\rightarrow \mathrm{P}^{\prime}$ 'Phosphoramidate DNA Templates. Nucleic Acids Res. 2019, 47 (17), 8941-8949.

(2) Prywes, N.; Blain, J. C.; Del Frate, F.; Szostak, J. W. Nonenzymatic Copying of RNA Templates Containing All Four Letters Is Catalyzed by Activated Oligonucleotides. Elife 2016, 5 (JUN), 1-14.

(3) Joyce, G. F.; Inoue, T.; Orgel, L. E. Non-Enzymatic Template-Directed Synthesis on RNA Random Copolymers Poly (C,U) Templates. J. Mol. Biol. 1984, 176, 279-306.

(4) Freier, S. M.; Kierzek, R.; Jaeger, J. A.; Sugimoto, N.; Caruthers, M. H.; Neilson, T.; Turner, D. H. Improved Free-Energy Parameters for Predictions of RNA Duplex Stability. Proc. Natl. Acad. Sci. 1986, 83 (24), 9373-9377.

(5) Sugimoto, N.; Nakano, S. ichi; Katoh, M.; Matsumura, A.; Nakamuta, H.; Ohmichi, T.; Yoneyama, M.; Sasaki, M. Thermodynamic Parameters To Predict Stability of RNA/DNA Hybrid Duplexes. Biochemistry 1995, 34 (35), 1121111216.

(6) Chen, J. L.; Dishler, A. L.; Kennedy, S. D.; Yildirim, I.; Liu, B.; Turner, D. H.; Serra, M. J. Testing the Nearest Neighbor Model for Canonical RNA Base Pairs: Revision of GU Parameters. Biochemistry 2012, 51 (16), 3508-3522.

(7) Wright, D. J.; Force, C. R.; Znosko, B. M. Stability of RNA Duplexes Containing Inosine-cytosine Pairs. Nucleic Acids Res. 2018, 46 (22), 12099-12108.

(8) Gryaznov, S. M. Oligonucleotide N3'-->P5' Phosphoramidates as Potential Therapeutic Agents. Biochim. Biophys. Acta 1999, 1489 (1), 131-140.

(9) Owczarzy, R.; Moreira, B. G.; You, Y.; Behlke, M. A.; Wälder, J. A. Predicting Stability of DNA Duplexes in Solutions Containing Magnesium and Monovalent Cations. Biochemistry 2008, 47 (19), 5336-5353. 